\title{
Bioaccumulation of Heavy Metals and Physiological Response in Anabas testudineus on Exposure to Paper Mill Effluent
}

Prasanta Nanda*

Department of Zoology, D. N. Government College, Itanagar, Arunachal Pradesh 791113, India

\begin{abstract}
Bioaccumulation of heavy metals and biochemical response in Anabas testudineus was investigated after exposing it to various concentrations $(0-40 \%)$ of paper mill effluent containing low level toxic metal ions. Maximum amount of zinc was accumulated in gills, however ovary was found to be the main target organ for $\mathrm{Zn}$ accumulation based on maximum accumulation factor. The increased content of metal ion in all the tissues at higher exposure level confirms the dose dependent accumulation of metal ion. Zinc accumulation follows the pattern gill> liver $>$ ovary $>$ muscle. Copper accumulation was highest in liver and the order of accumulation follows the trend gill $>$ liver $>$ muscle $>$ ovary. Cadmium bioaccumulation was significantly higher in all the tissues without showing any specific trend. Maximum cadmium and lead accumulation was observed in ovary. The trend of $\mathrm{Pb}$ accumulation followed the order ovary $>$ liver $>$ gill $>$ muscle. In terms of the type of metal accumulation in all the tissues together, the trend was $\mathrm{Zn}>\mathrm{Pb}>\mathrm{Cu}>\mathrm{Cd}$ while tissue specific total metal accumulation followed gills $>$ liver $>$ ovary $>$ muscle. The result of this study indicates that ovary acts as a major accumulator of heavy metals besides gill and liver in A. testudienus when exposed to paper mill effluent. Hematological parameters viz., Hb, TEC, hematocrit and $\mathrm{MCHC}$ showed significant $(\mathrm{p}<0.05)$ decrease in the exposed fish in comparison to the control value. While level of glucose (except liver) and protein depleted consistently, cholesterol level showed significant increase in plasma, liver and muscles. Physiological response upon exposure to PME indicates damage of tissues with loss of protein and impaired regulation of metabolic function as indicated by blood parameters.
\end{abstract}

Keywords: Bioaccumulation; Heavy metals; Paper mill effluent; Maximum accumulation factor; Physiological response; Anabas testudineus

\section{Introduction}

During last few decades, there has been considerable concern over heavy metals contamination of aquatic environment and the potential health threat to public potable water sources. The non-degradable and persistent nature of the metal ions results in longer exposure and accumulation of these substances in the aquatic flora and fauna. This would result in deterioration and disturbance of aquatic ecosystem. Heavy metal accumulation in the aquatic environment could result in toxicity to both aquatic life and human. Edible fish present in aquatic bodies form an important group of organism as heavy metal once accumulated in fish tissues could act as a potential carrier of metal ion along the food chain. At the end, directly or indirectly the metal ion in the aquatic medium reaches to the man. Hence several studies involving bioaccumulation of heavy metals have been conducted in fishes [1-4] found in river streams generally receiving industrial effluents containing toxic heavy metals and organic pollutants.

Accumulation of metals $(\mathrm{Cu}, \mathrm{Zn}, \mathrm{Cd}, \mathrm{Ni}, \mathrm{Cr}, \mathrm{Pb})$ in different tissues viz., blood, gill, gut, liver, muscle, kidney, ovary and gonad etc., have been extensively investigated in various fishes [3,5-9]. Most of these studies report metal accumulation indicating preference of the tissues for some metals over the others. The characterization of the accumulation of metals into different organs has proven to be a representative measure of the heavy metal exposure [10] and is used to monitor the bioavailability of these metals. Gills and livers are considered most important for assessing metal accumulation. Since gill is in direct contact with metal present in the water, the concentrations of metals in gills reflect the concentration of metals in water. Copper accumulation was found to be maximum in gills in O.niloticus [11] whereas highest $\mathrm{Cd}$ accumulation in gill was observed during long term sub lethal $\mathrm{Cd}$ exposure in rainbow trout [5]. The metal accumulation in liver and its concentration represent storage of metals contributing substantially to the overall metal load in the body. In addition to gill and liver, ovary involved in reproduction of fish is a metabolically active tissue and accumulate heavy metals of higher levels [7]. Amongst all the tissues in fish, muscle is not known as an active metal accumulator. Besides accumulation in tissues, changes in hematological and biochemical parameters have also been reported in several such studies [2,11-15]. These investigations have helped to understand the diversity in mechanism of heavy metal homeostasis in fishes although no universal mechanism could be established.

We conducted a series of study involving exposure of paper mill effluent (PME) containing trace level of heavy metals on Anabas testudineus, the climbing perch. Anabas testudineus (family, Anabantidae), was selected for this study since it is a popular edible fish widely available in the upper stream of river Ib, located at Brajarajnagar, in Jharsuguda district of Orissa state (India) which receives industrial discharge from the nearby situated paper mill effluent. Chemical analysis of paper mill effluent indicated presence of different heavy metals viz., $\mathrm{Cd}, \mathrm{Pb}, \mathrm{Cu}, \mathrm{Zn}$ etc., at a concentration less than $0.2 \mathrm{mg} / \mathrm{L}$ [16]. Our result on toxicity study showed that $A$. testidineus was more sensitive to the exposure of the paper mill effluent in comparison to the other two air breathing fishes viz. Clarias batrachus and Channa punctatus as indicated by their $\mathrm{LC}_{50}$ value [17]. Further investigation

*Corresponding author: Prasanta Nanda, Department of Zoology, D. N. Government College, Itanagar, Arunachal Pradesh 791113, India, Tel: +910360-2291809; E-mail: nandap71@rediffmail.com

Received August 11, 2014; Accepted Septemebr 29, 2014; Published October 01, 2014

Citation: Nanda P (2014) Bioaccumulation of Heavy Metals and Physiological Response in Anabas testudineus on Exposure to Paper Mill Effluent. J Environ Anal Toxicol 5: 244. doi: 10.4172/2161-0525.1000244

Copyright: (c) 2014 Nanda P. This is an open-access article distributed under the terms of the Creative Commons Attribution License, which permits unrestricted use, distribution, and reproduction in any medium, provided the original author and source are credited. 
in the same species showed substantial histopathological abnormalities including damage of hepatocytes, gills and intestinal villi upon exposure to the paper mill effluent [18]. In view of this, there is a need to investigate the cause of such damage to various organs when the fish is exposed to paper mill effluent. One of the possibilities could be presence of toxic metal ions. Though lesser in concentration, the toxic metal ions can damage the various tissues and organs if it is bioaccumulated. Therefore in the present study, investigation were carried out to find out the level of accumulation of different metal ions in these tissues and overall physiological (hematological and biochemical) response as an important aspect of understanding the toxic effect of paper mill effluent.

\section{Materials and Methods}

\section{Experimental set-up}

The paper mill effluent was collected from the integrated pulp and paper mill situated near the river Ib (Jharsuguda, Odisha, India). The concentration of different heavy metals found in the paper mill effluent was $\leq 0.2 \mathrm{ppm}$ [16]. The paper mill effluent was diluted with tap water to obtain different concentrations $(5,10,20$, and $40 \%)$ for further use. The tap water was used as a control ( $0 \%$ effluent) that did not contain any detectable heavy metals included in this study. Toxicity of the paper mill effluent $\left(\mathrm{LC}_{50}\right)$ on different air breathing fish has shown Anabas testudineus with highest tolerance [17]. Therefore, this fish was selected to carry out the current study. Healthy specimens of $A$. testudineus were collected from the upper stream, i.e., above the point at which the paper mill effluent enters into the river Ib (Odisha, India). The weight and length of the specimens selected for the study was in the range of 20-22 $\mathrm{g}$ and $10-12 \mathrm{~cm}$ respectively. Each set of treatment included exposure of 10 adult specimens in a glass aquarium $(50 \mathrm{~cm} \times 50 \mathrm{~cm} \times 45$ $\mathrm{cm}$ ) containing $20 \mathrm{~L}$ of paper mill effluent of desired concentration for 30 days. Temperature was maintained at $26 \pm 2^{\circ} \mathrm{C}$, aeration was continuous and medium static. The medium was replaced every 3 days over the 30 days period and fish were fed with commercial fish food.

\section{Tissue metal analysis}

At the end of the exposure period, gill, liver, muscle, and ovary were dissected out. The tissues were oven dried at $60^{\circ} \mathrm{C}$ till constant weight. After determination of the dry weight the tissues were digested at $70^{\circ} \mathrm{C}$ in an aluminium block heater in screw capped polypropylene tubes with a mixture of $2 \mathrm{ml} \mathrm{HNO}_{3}$ and distilled water $(1: 1 \mathrm{~V} / \mathrm{V})$. The heavy metal $(\mathrm{Cd}, \mathrm{Cu}, \mathrm{Pb}$, and $\mathrm{Zn})$ contents of the tissue digests were determined using an Atomic Absorption Spectrophotometer (GBC902). Atomic absorption standards procured from Sigma were used in the analysis. The amount of metal accumulation was expressed as $\mu \mathrm{g}$ metal ion/g dry weight of the tissue. Based on the metal accumulation value, the term 'maximum accumulation factor' was derived. This represents ratio of highest metal accumulation in tissues of the effluent exposed fish and accumulation in the same tissues of the control fish.

\section{Hematology and tissue biochemistry}

At the end of exposure period blood (1.5-2.0 mL) was collected from the caudal peduncle artery into heparinised tubes. Hemoglobin $(\mathrm{Hb})$, total erythrocyte count (TEC), hematocrit and total leucocyte count (TLC) were determined and mean cell hemoglobin ( $\mathrm{MCH})$, mean cell hemoglobin concentration (MCHC), and mean cell volume (MCV) were calculated following the standard protocol (Dacie and Lewis). Plasma was separated from cells by centrifugation of whole blood at $1500 \mathrm{x} \mathrm{g}$ for $10 \mathrm{~min}\left(4^{\circ} \mathrm{C}\right)$. Liver and muscle tissues were dissected out. Biochemical parameters viz., protein, glucose and cholesterol were determined spectrophometrically in blood plasma, liver and muscle tissues following the procedure of Lowry et al. [19], Trevelyan and Harrison [20] and Libberman-Burchard [21] respectively.

\section{Statistical Analysis}

All results expressed are mean \pm standard deviation $(n=10)$, i.e., each data points are average of 10 separate fish samples. The differences in mean metal accumulation were analyzed using one-way analysis of variance (ANOVA). Statistical significance was assessed at $p<0.05$. All statistical operations were performed using Micrococal Origin (Version, 6.0).

\section{Results}

In our previous study, three types of air breathing fish found in the river viz., Clarius batrachus, Chana punctatus and Anabas testudienius were evaluated for their tolerance. When all these fish were exposed to Paper Mill Effluent, A. testudineus showed maximum $\mathrm{LC}_{50}$ [17] and therefore being most tolerant the same fish was used in the present study.

\section{Metal accumulation in tissues}

Accumulation of zinc ( $\mu \mathrm{g} / \mathrm{g}$ dry weight) in different tissues is presented in Figure 1. The highest quantity of zinc $(332.9 \pm 2.9, \mu \mathrm{g} / \mathrm{g}$ dry weight) was accumulated in gill exposed to $40 \%$ paper mill effluent and this was significantly $(\mathrm{P}<0.05)$ higher from other tissues (liver, ovary, and muscles). High level of $\mathrm{Zn}$ accumulation ( $\mu \mathrm{g} / \mathrm{g}$ dry weight) was also found in liver $(283.4 \pm 9.4)$ and ovary $(231.8 \pm 7.0)$. Muscle accumulated lowest quantity of zinc ( $56 \pm 0.6 \mu \mathrm{g} / \mathrm{g}$ dry weight) among all the tissues investigated. Zinc content in all the tissues increased with increasing concentration of the paper mill effluent and was highest in fish exposed to $40 \%$ effluent. The accumulation of zinc in gill, liver, and ovary tissues was significantly $(\mathrm{P}<0.05)$ different at all level of exposure (5-40\%) in comparison to the control. The increased content of metal ion in all the tissues at higher exposure level has further confirmed the dose dependent accumulation of metal ion. Although the pattern of metal accumulation in the $40 \%$ effluent treated fish was gill $>$ liver $>$ ovary $>$ muscle, the trend of maximum accumulation factor was different. The highest accumulation factor was observed in ovary (4.08) followed by gill (2.85), liver (2.53) and muscle (1.83). This result

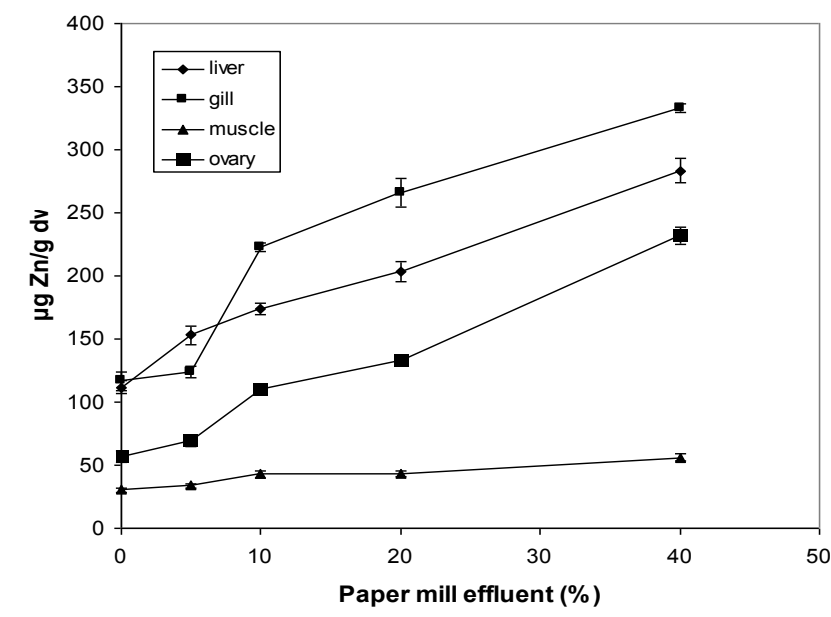

Figure 1: Zinc concentrations ( $\mu \mathrm{g} / \mathrm{g}$ dry weight) in tissues of the climbing perch after exposure for 30 days to paper mill effluent. 


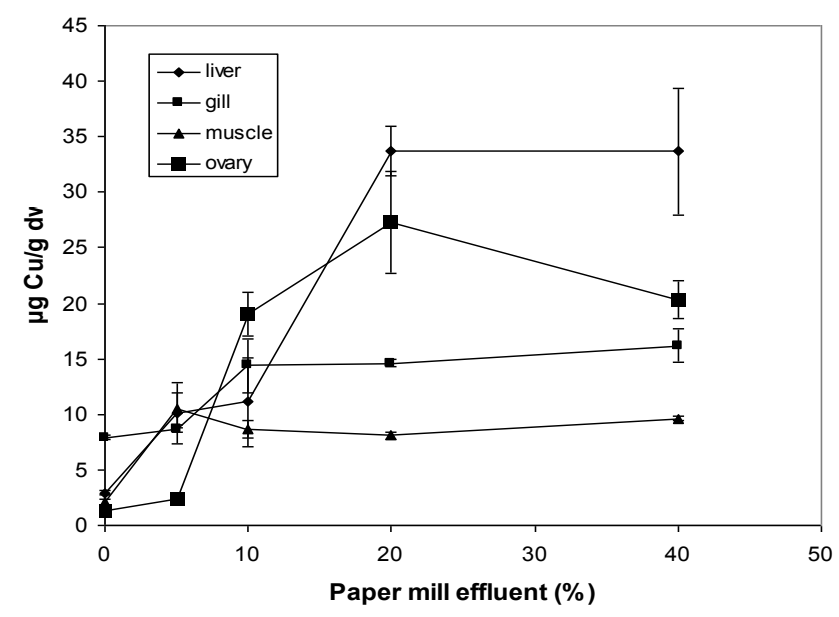

Figure 2: Copper concentrations ( $\mu \mathrm{g} / \mathrm{g}$ dry weight) in tissues of the climbing perch after exposure for 30 days to paper mill effluent.

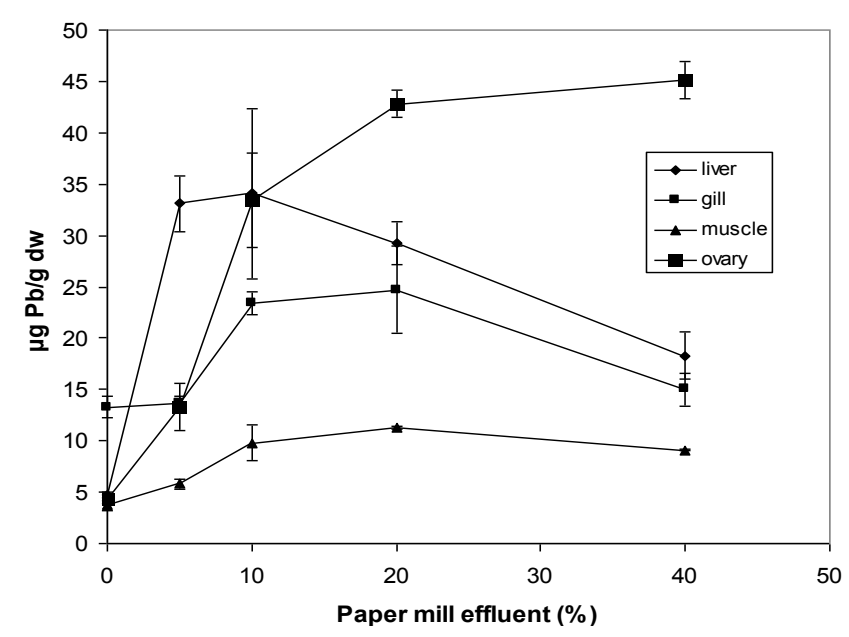

Figure 3: Cadmium concentrations ( $\mu \mathrm{g} / \mathrm{g}$ dry weight) in tissues of the climbing perch after exposure for 30 days to paper mill effluent.

indicate ovary as a target organ in terms of the number of times $\mathrm{Zn}$ was accumulated in effluent exposed fish in comparison to the control.

Copper accumulation was highest in liver $(33.7 \pm 5.7, \mu \mathrm{g} / \mathrm{g}$ dry weight) followed by ovary, gill and muscle (Figure 2). The distribution of copper in control group was gill $>$ liver $>$ muscle $>$ ovary. This trend was completely different to the trend of accumulation, liver $>$ ovary $>$ gill $>$ muscle observed in fish exposed to $40 \%$ effluent. Copper accumulation was significantly $(\mathrm{P}<0.05)$ high in all tissues and at all exposed concentration of effluent. However there was no significant difference between $\mathrm{Cu}$ accumulation in the gills of the fish exposed to 10 and $20 \%$ effluent. In muscle, the maximum amount of metal ion $(10.5 \pm 1.5, \mu \mathrm{g} / \mathrm{g}$ dry weight) was found in fish exposed $5 \%$ effluent. The accumulation of copper remained almost independent of concentration after this level of exposure. The maximum accumulation factor followed the trend ovary (15.11) > liver (11.79) > muscle (4.93)> gill (2.05).

Accumulation of cadmium in different tissues indicated the trend ovary $>$ liver $>$ gill $>$ muscle (Figure 3 ). Maximum quantity of cadmium $(7.3 \pm 0.3 \mu \mathrm{g} / \mathrm{g}$ dry weight $)$ was observed in ovary. The accumulation was only $1.5 \pm 0.2 \mu \mathrm{g} \mathrm{Cd} / \mathrm{g}$ dry weight in muscle.
Cadmium concentration in the muscle tissues of the fish exposed to $5 \%, 10 \%$ and $20 \%$ effluent showed no significant $(\mathrm{P}>0.05)$ difference between each other, however they were significantly $(\mathrm{P}<0.05)$ different when compared to $40 \%$ effluent treated fish and the control. Similar trend was observed for cadmium accumulation in ovary of the fish exposed to $5 \%, 10 \%$ and $20 \%$ effluent. Interestingly, a sharp increase (43.75\%) in Cd accumulation was observed when the exposed effluent concentration increased from $20 \%$ to $40 \%$ in case of ovary tissue. Liver showed maximum accumulation $(2.9 \pm 0.8 \mu \mathrm{g} / \mathrm{g}$ dry weight $)$ at $5 \%$ exposure, while maximum accumulation $(2.3 \mu \mathrm{g} / \mathrm{g}$ dry weight $)$ in gill was observed at $10 \%$ exposure level. The maximum accumulation factor followed the order muscle (5.84) $>$ ovary (5.52) $>$ gill (3.6) $>$ liver (3.25). Though significantly higher accumulation was observed in these tissues at all exposed concentration no specific trend was observed.

The trend of $\mathrm{Pb}$ accumulation followed the order ovary $>$ liver $>$ gill $>$ muscle (Figure 4). However, the maximum accumulation factor indicated the trend ovary (10.51)> liver (7.22)> muscle (3.07) $>$ gill (1.86). Maximum accumulation of lead observed in ovary was $45.1 \pm 1.8 \mu \mathrm{g} / \mathrm{g}$ dry weight. Metal ion content increased in ovary with increasing exposure concentration while in other tissues no particular trend was observed. In control tissues the accumulation of $\mathrm{Pb}$ followed gill $>$ liver $>$ ovary $>$ muscle. Fish exposed to $5 \%$ effluent exhibited 7 fold enhancements in liver $\mathrm{Pb}$ concentration in comparison to the control. This level of $\mathrm{Pb}$ concentration built up was maintained in the liver in subsequent higher doses of exposure (10 and $20 \%$ effluent), which finally declined to 3.9 fold increase at $20 \%$ level. Similar trend of uptake was also observed in gills and muscles. Lead accumulation was significantly $(\mathrm{P}<0.05)$ different in comparison to the control in all the tissues at all exposed concentration except in gill at 5\% exposure.

\section{Hematology}

Hematological parameters viz., Hb, TEC, hematocrit and MCHC showed significant $(\mathrm{p}<0.05)$ decrease in the exposed fish in comparison to the control value (Table 1). The changes in the hematological parameters were concentration dependent and least values were observed at highest exposure level (40\%). While hemoglobin concentration decreased by 2.9 fold at $40 \%$ exposure level, the total erythrocyte count decreased by 3.7 fold that is reflected in enhancement of MCH value. In contrast, MCV increased by 1.6 fold at highest concentration of exposure ( $40 \%$ effluent). Total leucocytes

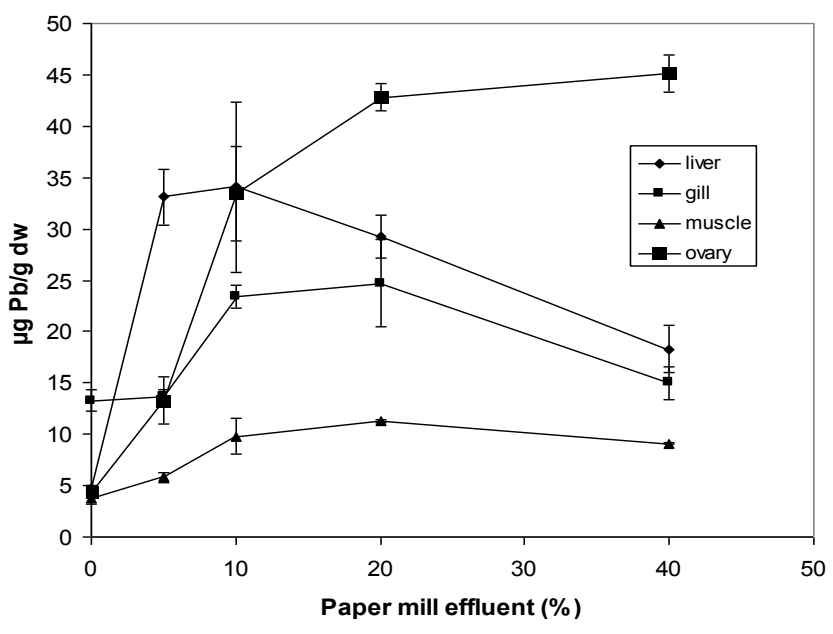

Figure 4: Lead concentrations ( $\mu \mathrm{g} / \mathrm{g}$ dry weight) in tissues of the climbing perch after exposure for 30 days to paper mill effluent. 


\begin{tabular}{|c|c|c|c|c|c|}
\hline \multirow{2}{*}{ Parameters } & \multicolumn{5}{|c|}{ Paper mill effluent (\%) } \\
\hline & 0 & 5 & 10 & 20 & 40 \\
\hline $\mathrm{Hb}(\mathrm{g} \%)$ & $12.59 \pm 2.4$ & $11.67 \pm 3.3$ & $6.4 \pm 2.7$ & $4.7 \pm 2.4$ & $4.31 \pm 0.21$ \\
\hline TEC $\left(\times 10^{6} / \mathrm{mm}^{3}\right)$ & $2.6 \pm 0.23$ & $2.31 \pm 1.4$ & $1.78 \pm 0.2$ & $0.78 \pm 0.7$ & $0.7 \pm 0.4$ \\
\hline Hematocrit (\%) & $45.43 \pm 0.6$ & $43.82 \pm 0.13$ & $33.75 \pm 2.43$ & $24.82 \pm 0.13$ & $19.53 \pm 0.48$ \\
\hline $\mathrm{MCH}(\mathrm{pg})$ & $48.52 \pm 3.02$ & $50.42 \pm 3.78$ & $56.33 \pm 3.99$ & $60.14 \pm 3.68$ & $61.66 \pm 5.88$ \\
\hline MCHC (\%) & $27.74 \pm 2.28$ & $26.64 \pm 1.5$ & $19.2 \pm 1.8$ & $19.0 \pm 1.71$ & $21.16 \pm 3.72$ \\
\hline $\operatorname{MCV}\left(\mu^{3}\right)$ & $176.74 \pm 21.9$ & $189.35 \pm 14.43$ & $189.66 \pm 32.04$ & $316.87 \pm 28.2$ & $279.16 \pm 54.03$ \\
\hline $\operatorname{TLC}\left(\times 10^{3}\right)$ & $15.71 \pm 2.43$ & $16.39 \pm 1.02$ & $35.93 \pm 2.25$ & $44.06 \pm 1.77$ & $53.01 \pm 2.97$ \\
\hline
\end{tabular}

Table1: Hematological parameter of $A$. testudineus exposed to paper mill effluent.

count increased with increasing effluent exposure concentration, finally gaining a 3.7 fold increase in cell numbers at $40 \%$ exposure level.

\section{Tissue biochemistry}

Plasma, liver and muscle tissues were investigated for assessing the effect of metal accumulation on biochemical parameters such as glucose, protein and cholesterol. While level of glucose (except liver) and protein depleted consistently, cholesterol level increased significantly $(\mathrm{p}<0.05)$ upon increasing exposure to higher concentration of PME (5 - 40\% concentration) (Figure 5a-c). There was sudden decline in the glucose content of PME exposed fish $(40.3 \pm 3.2 \mathrm{mg} / \mathrm{dl})$ at lowest concentration $(5 \%)$ from the control value $(48.2 \pm 4.9 \mathrm{mg} / \mathrm{dl})$ in plasma. With further increase in concentration to $10 \%$ effluent glucose level decreased to $38.1 \pm 3.5 \mathrm{mg} / \mathrm{dl}$ beyond which it remained constant at $32 \mathrm{mg} / \mathrm{dl}$. Similar decreasing trend was observed for glucose level in the muscle. In contrast, glucose level increased with increasing effluent concentration with a maximum of 2.3 fold at highest concentration of exposure. Deproteination is clearly observed in fish exposed to PME of different concentration at all concentration across all tissues. The loss of protein was highest in muscle followed by plasma and liver. The effect was such that at higher concentrations (40\%) only one fourth amount of protein remained in muscle. However cholesterol level shows a different trend. The overall increase in plasma cholesterol level was concentration dependant. There was a significant $(p<0.05)$ increase in the plasma cholesterol level in PME (40\%) exposed fish (423.9 \pm 21.5 $\mathrm{mg} / \mathrm{dl})$ in comparison to the control fish $(226.4 \pm 10.5 \mathrm{mg} / \mathrm{dl})$. Similarly increasing trend in cholesterol level was observed for liver and muscle.

\section{Discussion}

\section{Metal accumulation in tissues}

The major objective of this study was to assess the accumulation and distribution of heavy metals $(\mathrm{Zn}, \mathrm{Cu}, \mathrm{Cd}$, and $\mathrm{Pb})$ in different tissues (gill, liver, ovary, and muscle) and its effect on hematological and biochemical parameters of $A$. testudineus exposed to paper mill effluent to understand the toxic effect. Amongst the heavy metals included in our study $\mathrm{Zn}$ and $\mathrm{Cu}$ are two important essential metals required for the normal cellular metabolism of the fish. This indicates that entry of these metals will follow the normal route of uptake when the fish are exposed to the effluent contaminated with such pollutants. In the case of fish the uptake of metal ions occurs through three major routes namely body surface, gill, and alimentary canal [22]. In general, $\mathrm{Zn}$ content in the control tissue (liver, gill, muscle and ovary) was higher in comparison to the other metals investigated in this study (Figure 1-4). A high amount of $\mathrm{Zn}$ in comparison to other elements is typical for fish [23]. The uptake of $\mathrm{Zn}$ by gills has been shown to be an active process. It is generally believed that fish activity regulates $\mathrm{Zn}$ concentration in their muscle tissue. As a result change in ambient availability of $\mathrm{Zn}$ in the environment is not reflected in the tissues of fish. Accumulation of $\mathrm{Zn}$ induces a depressive effect on tissue respiration which is consistent
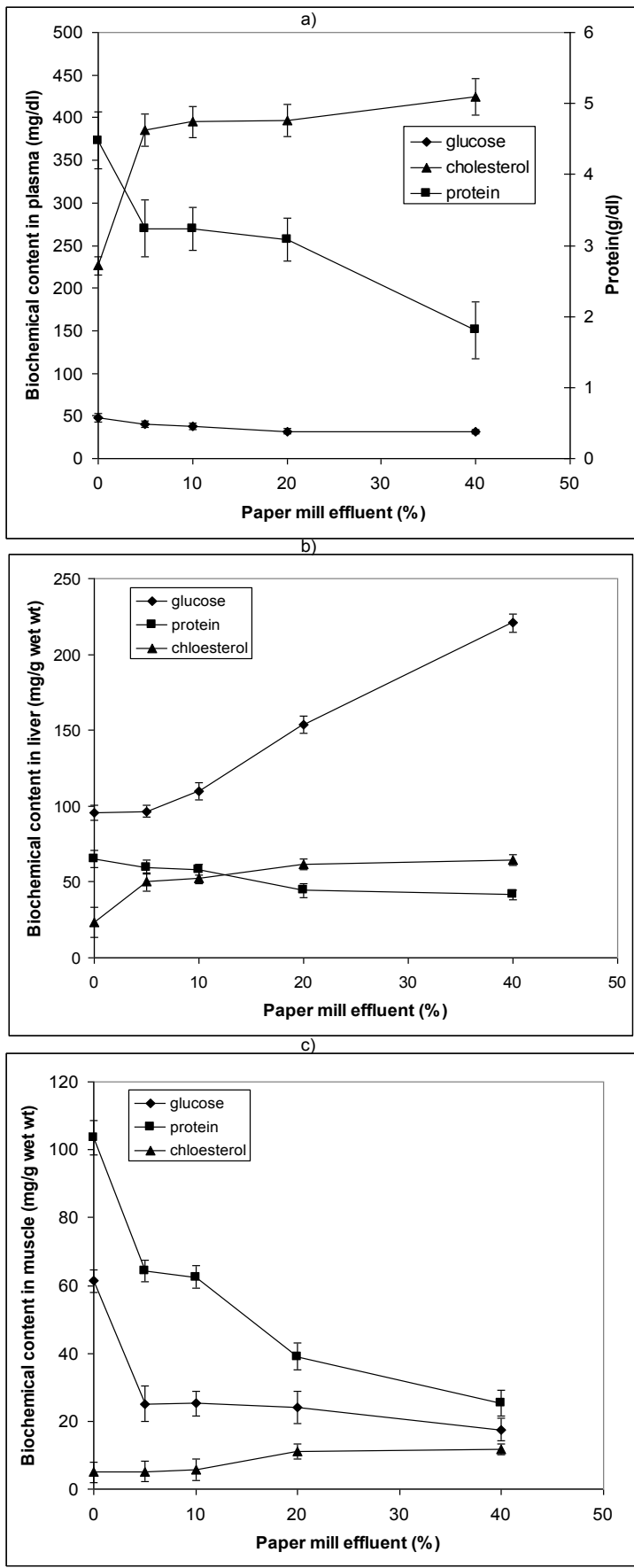

Figure 5: Biochemical content (glucose, protein and cholesterol) after exposure to paper mill effluent (a) in plasma, (b) liver and (c) muscle. 
with a general deficiency of oxygen in the whole fish that could lead to possible death by hypoxia. However, incomplete regulation leads to enhanced accumulation of this element in gill and alimentary canal [24]. Our observation of very high accumulation of $\mathrm{Zn}$ in gill (332.9 $\pm 2.9 \mu \mathrm{g} / \mathrm{g}$ dry weight) may be a result of similar failure in regulating mechanism in the fish exposed to paper mill effluent. The accumulation and distribution of metallic element in tissues/organs depends on the route through which it enters into the body that may be linked to the feeding habits. The trend of $\mathrm{Zn}$ accumulation in A. testudineus with highest accumulation observed in gills indicates that major route of entry of this metal was gill. Interestingly, in the present study ovary has shown highest zinc accumulation factor (4.08) compared to the control amongst all the tissues investigated. This indicates that besides gill and liver, ovary was a target organ for $\mathrm{Zn}$ accumulation in A. testudineus that might affect the reproduction mechanism of the fish. Vitellogenin (VTG) is important for oocyte development, a developmental phase responsible for enormous oocyte growth, where heavy metals (contaminant products) along with the essential nutrients are taken up and stored for future embryo development. Metals can also bind to different sex-linked proteins (lipoproteins and phosphoproteins) and lipids by binding to receptor mediated uptake of VTG present in fish ovaries [25]. The major edible part of the fish is muscle. Accumulation of metal ion in this tissue would have significant effect on transfer of this metal to the human being through food chain. However the accumulation of $\mathrm{Zn}$ was least in muscle tissues of A. testudineus and is comparatively a less likely target organ for $\mathrm{Zn}$.

Liver and gills are known to be target organs for $\mathrm{Cu}$ in fish. The $\mathrm{Cu}$ content of the gill among all tissues in control fish was highest reflecting the intensive biochemical processes in this organ. However, $\mathrm{Cu}$ accumulation pattern did not follow the same trend in effluent exposed fish. In fact, maximum amount of copper accumulation was observed in liver followed by ovary. Our observation of liver as the main organ for copper accumulation agrees with the finding of liver as the target organ in Clarias gariepinus exposed to sub lethal levels of tannery effluent [2]. Similar result has also been reported by Moiseenko and Kudryavtseva [23]. An important deviation in $\mathrm{Cu}$ uptake in comparison to other metals was observation of a saturation effect on $\mathrm{Cu}$ accumulation in liver and gills beyond $20 \%$ and $10 \%$ effluent exposure respectively. Such phenomenon has been suggested to occur when the net uptake of copper at the apical membrane of the gill is equalized by transport across the basolateral membrane into the blood [26]. In another study, Nair et al. [24] have observed maximum accumulation of $\mathrm{Zn}$ and $\mathrm{Cu}$ in gills and alimentary canals of marine fish collected from Cochin, the southern coast of India.

Cadmium is an oxyphllic and sulfophillic element. It has affinity for multiple bonding in the body forming stable complexes with variety of organic compounds. In fish, cadmium has adverse effects on growth, inhibits calcium uptake in gills and alters liver function [27]. Barber and Sharma [28] observed maximum accumulation of Cd in kidney of fresh water fishes Labeo rohita $(0.1558 \mathrm{mg} \mathrm{Cd} / \mathrm{g})$ and Catla catla $(0.1606 \mathrm{mg} \mathrm{Cd} / \mathrm{g})$ exposed to $\mathrm{Zn}$ smelter effluent. In both the fish, kidney accumulated maximum amount of $\mathrm{Cd}$ followed by gill whereas liver and muscle contained less cadmium. However, maximum accumulation was found in gill in Channa punctatus $(0.0899 \mathrm{mg} \mathrm{Cd} / \mathrm{g})$. Using blue gill (Lepomis macrochirus) Mount and Stephan [29] found maximum amount of $\mathrm{Cd}$ accumulation in kidney, liver, gill and gut but not significantly in bone and muscle. While studying $\mathrm{Cd}$ accumulation in Cyprinus carpio, Vincent and Ambrose [30] observed maximum accumulation in gill. Significant amount of zinc and cadmium accumulation was seen in the alimentary canal in Mystus vittatus collected from Mehadrigedda stream (Vishakhapatnam, India) [22]. In contrast to all these studies, our observation suggests that reproductive organ such as ovary tissues of $A$. testudineus was the major site of Cd accumulation.

Lead accumulation was mainly observed in liver and kidney by Moiseenko and Kudryavtseva [23]. The background concentration of $\mathrm{Pb}$ was very high in gills compared to other organs in our study. Maximum amount of $\mathrm{Pb}$ found in ovary is a rare observation. However, higher accumulation in liver as shown in Figure 4 was similar to the findings of Allen [31]. Further, lowest concentration of $\mathrm{Pb}$ as observed in muscle tissues of $A$. testudineus was similar to the finding of Oladimeji and Offem [32]. This might be attributed to the high growth factor of muscle tissue as growth may dilute the toxicant concentration [2].

In this study, metal accumulation in whole fish (Liver + gill+ muscle+ ovary) was in the order of $\mathrm{Zn}>\mathrm{Pb}>\mathrm{Cu}>\mathrm{Cd}$ and tissue specific total metal accumulation $(\mathrm{Zn}+\mathrm{Cu}+\mathrm{Cd}+\mathrm{Pb})$ was gills $>$ liver $>$ ovary $>$ muscle. The variation in metal accumulation in different tissues could be due to difference in permeability of the tissues that would determine the quantity of metal entering into the cells. There could be competition for the protein binding sites both at the mucosal cell level and in tissues. Another important factor that could play a significant role in determining the fate of each metal is presence of multiple metal ions together in the same medium such as the paper mill effluent. This condition is completely different form the studies on accumulation of metals performed in isolation with single metal component in the system. It is well known that when metals occur in association they can interact and the critical concentration of the toxic effects of some may be altered [33]. Possible mechanisms of metal-metal interaction include interchange of metal bound proteins, induction of metal binding proteins, and formation of compound complexes among metals. In interchange of metal-bound proteins competitions for carrier proteins may affect the transport of metal ions. Such as interaction between copper and $\mathrm{Zn}$ could be partly explained by competitions for binding sites on a protein carrier such as albumin in blood plasma [2].

Under metal stress several organisms synthesize a special type of protein, metallothionein (the metal binding protein) that helps in detoxification of the metal ion by binding and storing it as a constituent [34]. Metallothioneins are low molecular weight cystein rich protein that can selectively bind heavy metals [35]. Expression of metallothionein may equip several species enabling them to adapt and survive in mildly contaminated media. These proteins bind specifically to neutrally essential trace elements, such as $\mathrm{Zn}$ and $\mathrm{Cu}$, as well as to potentially toxic metal as $\mathrm{Cd}$ and $\mathrm{Hg}$ [23]. This may be a reason for accumulation of high quantity of $\mathrm{Zn}, \mathrm{Cd}, \mathrm{Cu}$ and $\mathrm{Pb}$ in liver, gills and ovary of A. testudineus. Further, this study reveals the differences in the distribution of metal ion accumulation in different tissues of the fish A. testudineus. Higher quantity of metal ion (especially zinc, cadmium and lead) accumulation observed in this study for reproductive tissue such as ovary is very rare.

\section{Hematology}

Depletion in Hb, TEC, PCV and MCHC (Table 1) upon exposure to paper mill effluent indicates anaemia in A. testudineus. This may be attributed to the deficit in iron and its utilization in haemoglobin synthesis as observed in $H$. fossilis upon exposure to sublethal concentration of $\mathrm{Ni}$ [36]. Decreased iron uptake in intestinal villi which is evident from our previous work [18] led to poor oxygen transport [37]. This is in agreement with adverse affect on respiratory 
metabolism due to exposure of PME on O. mossambicus [38]. Depletion may also be due to inhibitory effect on 5- amino, levulinate synthetase [39]. Increase in $\mathrm{MCH}, \mathrm{MCV}$ suggests that anemia is macrolytic type similar to the report in Tilapia mossambica exposed to Cd [40]. Cadmium can compete with iron for the same binding site and thereby inhibit iron uptake. Increase in TLC indicates leucopoesis which is an adaptive response to the new environment against toxicant $[41,42]$. No change was observed in $\mathrm{Hb}$ and hematocrit in C. carpio during upon $\mathrm{Cd}$ exposure [13]. Increase in $\mathrm{Hb}$ and hematorit in Salmo gairdneri exposed to $\mathrm{Cr}$ [43]. Increase in $\mathrm{Hb}$ and hematocrit in fish in response to $\mathrm{Zn} \mathrm{[44]} \mathrm{and} \mathrm{Cd}$ [45] has been reported. Cadmium exposure has been found to increase blood oxygen carrying capacity in rainbow trout [14]. Hemoglobin content and number of RBC showed no differences between control and $\mathrm{Pb}$ exposed fish Anguilla anguilla [46]. C. gariepinus did not show any difference in hematological parameters such as red cell count, $\mathrm{Hb}$, and hematocrit on exposure to dietary $\mathrm{Cu}$ [15].

\section{Tissue biochemistry}

Fish exposed to varying concentration of PME were analyzed to study the tissue specific changes in their biochemical status. The overall result (Figure 5a-5c) showed decreased glucose level (except the liver) and protein in all tissues with increasing concentration of PME exposure. This was accompanied by concomitant increase in cholesterol level in all tissues. Hence, clearly indicating the nutritional stress experienced by the fish on exposure to the effluent. Hypoghycemia in plasma may be due to low blood cortisol level. Lower plasma glucose may be due to decrease glucose uptake across the intestinal wall [18], while increase in liver glucose level may be attributed to retardation of glycogenolysis due to decrease in glucose-6-phosphate activity. Impaired glucose homeostasis was suggested as a possible reason for reduction of blood glucose in Salmo gairdneri exposed to inorganic lead [47]. Hyperglycemia in liver is a case of activated carbohydrate metabolism. Impaired homeostasis could lead to decreased plasma glucose in dietry Cd exposed rainbow trout [14]. In vitro study suggests that Cd impairs basal or epinephrine stimulated glucose release from eel hepatocytes [48]. Hyperglycemia in liver seemed to be more persistent on fish exposed to a simulated metal contaning effluent from a sulphide ore smeltery [49]. Increase in plasma glucose level of O. niloticus induced by copper [11] may be associated with the activation of the hypothalamussympathetic chromaffin cell axes [50]. An increase concentration of glucose in the plasma indicates activated carbohydrate metabolism as a response in $O$. mossambicus to sublethal copper exposure [12]. Increased in plasma glucose levels in cat fish exposed to abandoned coal mines drainage may be due to glucose mobilization in response to environmental stress that eventually decreased and then return to normal levels after 28 days of exposure [51].

Significant decline in protein content was observed in A. testudienus suggesting intensive proteolysis or reduced protein synthesis. Damage of the tissues [18] and proteolysis may be due to elevated protease, aspartate aminotranferase and alanine aminotansferase activity [13]. Decrease in protein in sunfish population exposed to coal ash effluent could be due to nuitritional stress [2]. Vijayram and Vasugi [52] reported depletion in protein level in tissues of Rasbora daniconius on exposure to paper mill effluent, whereas Singh et al. [53] reported hypoproteinemia in fish Heteropneustes fossilis treated with tannery effluent. This may be due to the reduced amino acid absorption in intestine [54]. Depletion of protein and glucose and increased cholesterol level in liver was observed in H. fossilis exposed to nickel [36].

Cholesterol level can be used as indicator of feeding and nutritional status [2]. Our result showed increased cholesterol content upon exposure to PME in A. testudienus. Similar report of increase in cholesterol followed by metal exposure has been reported in Oreochromis niloticus [55]. Plasma cholesterol level increased after acute and chronic exposure to mercury in Ophiocephalus punctatus [56]. Increase in cholesterol may be due to impair regulation of liver function [18] and as a mechanism to sequester lipophilic xenobiotics [57].

\section{Overall impact of metal accumulation on the fish metabolism}

The current results indicate that metal ions present in the Paper Mill Effluent enter into the fish through gills. Thereafter, it would enter into the blood and gets transported through the blood to various organs such as liver, muscle and ovary. The highest metal accumulation factor observed for the metal ions zinc, copper and lead indicates ovary as the target organ for all these heavy metals which would ultimately affect reproductive process. Damage to the liver and muscles due to increased accumulation of metal ions would adversely affect the detoxification process causing increased toxicity and degradation of muscles leading to protein depletion. In case of cadmium, the amount of metal ions accumulated was highest in ovary, although the accumulation factor was marginally lower than muscle tissue. Accumulation of cadmium preventing iron uptake could cause anemia [41,42] which has been observed in this study. Reduced supply of oxygen would adversely affect the central metabolic pathway including TCA cycle, glycolysis and gluconeogenesis leading to shortage of energy and slowing down conversion of intermediates to other building blocks thereby affecting glucose, cholesterol and protein metabolism.

\section{Conclusion}

Exposure to paper mill effluent (PME) resulted in significant accumulation of metal ions in different tissues of Anabas testudienus. Accumulation of metal ions in gills established this as a major route for entry of metal ion. Zinc was accumulated highest in the fish and cadmium the lowest. Interestingly, besides gills and liver, ovary was found to be a target organ for metal accumulation with highest maximum accumulation factor. Metal accumulation leading to anemia was evident with decrease in hemoglobin, TEC, PCV and MCHC indicating impaired metal homeostasis. Decrease protein content due to damage of the muscle tissue showed $75 \%$ of the protein was lost after exposure to PME. Increase in cholesterol content in all the tissues indicates metal exposure through PME leading to loss of regulation in liver function. The overall result indicates that heavy metal present in the paper mill effluent leading to its accumulation in various tissues following the exposure could cause toxicity to A. testudienus and therefore may be harmful for human consumption.

\section{References}

1. Hontela A, Daniel C, Rasmussen JB (1997) Structural and functional impairment of the hypothalamo- pituitary-interrenal axis in fish exposed to bleached kraft mill effluent in the St Maurice River, Quebec. Ecotoxicol 6: 10-12.

2. Lohner TW, Reash RJ, Willet VE, Fletcher J (2001) Assessment of tolerant sunfish populations (Lepomis Sp.) inhabiting selenium-laden coal ash effluents. Ecotoxicol Environ Saf 50: 225-232.

3. Gbem TT, Balogun JK, Lawal FA, Annune PA (2001) Trace metal accumulation in Clarias gariepinus (Teugels) exposed to sublethal levels of tannery effluent. Sci Total Environ 271: 1-9.

4. Linton ED, Scuton DA, McKinley RS (2005) Physiological effects of thermomechanical newsprint mill effluent on Atlantic salmon (Salmo salar L.) Ecotoxicol Environ Saf 62: 317-330.

5. Hollis L, McGeer JC, McDonald DG, Wood CM (2000) Effects of long term sublethal $C d$ exposure in rainbow trout during soft water exposure: implications for biotic ligand modelling. Aquat Toxicol 51: 93-105. 
Citation: Nanda P (2014) Bioaccumulation of Heavy Metals and Physiological Response in Anabas testudineus on Exposure to Paper Mill Effluent J Environ Anal Toxicol 4: 244. doi: 10.4172/2161-0525.1000244

6. Ptashynski MD, Pedlar RM, Evans RE, Baron CL, Klaverkamp JF (2002) Toxicology of dietary nickel in lake whitefish (Coregonus clupeaformis). Aquat Toxicol 58: 229-247.

7. Yilmaz $A B(2003)$ Levels of heavy metals ( $\mathrm{Fe}, \mathrm{Cu}, \mathrm{Ni}, \mathrm{Cr}, \mathrm{Pb}$, and $\mathrm{Zn}$ ) in tissue of Mugil cephalus and Trachurus mediterraneus from Iskenderun Bay, Turkey. Environ Res 92: 277-281.

8. Boeck GD, Meeus W, Coen WD, Blust R(2004) Tissue-specific Cu bioaccumulation patterns and differences in sensitivity to water borne copper in three fresh water fish: rainbow trout (Oncorhynchus mykiss), common carp (Cyprinus carpio), and gibel carp (Carassius auratus gibelio). Aquat Toxicol 70 : 179-188.

9. Alquezar R, Markich SJ, Booth DJ (2006) Metal accumulation in the smooth toadfish, Tetractenos glaber, in estuaries around Sydney, Australia. Environ Pollut 142: 123-131.

10. Serafim MA, Bebianno MJ (2001) Variation of metallothionein and metal concentrations in the digestive gland of the clam Ruditapes decussatus: sex and seasonal effects. Environ Toxicol Chem 20: 544-552.

11. Monteiro SM, Mancera JM, Fontaínhas-Fernandes A, Sousa M (2005) Copper induced alterations of biochemical parameters in the gill and plasma of Oreochromis niloticus. Comp Biochem Physiol C Toxicol Pharmacol 141: 375-383.

12. Pelgrom SMGJ, Lock RAC, Balm PHM, Bonga SEW (1995) Integrated physiological response of tilapia, Oreochromis mossambicus, to sublethal copper exposure. Aquat Toxicol 32: 303-320.

13. De Smet $H$, Blust $R$ (2001) Stress responses and changes in protein metabolism in carp Cyprinus carpio during cadmium exposure. Ecotoxicol Environ Saf 48 : 255-262.

14. Chowdhury MJ, Pane EF, Wood CM (2004) Physiological effects of dietary cadmium acclimation and waterborne cadmium challenge in rainbow trout: respiratory, ionoregulatory, and stress parameters. Comp Biochem Physiol C Toxicol Pharmacol 139: 163-173.

15. Hoyle I. Shaw BJ, Handy RD (2007) Dietary copper exposure in the African walking catfish, Clarias gariepinus: transient osmoregulatory disturbances and oxidative stress. Aquat Toxicol 83: 62-72.

16. Nanda P, Panigrahi S, Behera MK (1999) Physico-chemical and microbia analysis of the Orient paper mill effluent. Environ Ecol 17: 975-977.

17. Nanda P, Panigrahi S, Nanda B, Behera MK (2000) Toxicity of paper mill effluent to fishes. Environ Ecol 18: 220-222.

18. Nanda P, Panigarhi S, Nanda BR, Behera MK, Kaliali E (2004) Histopathological changes in climbing perch, Anabas testudineus BlockAnabantidae: Perciformes due to three granular insecticides. Environ Ecol 22: 24-25.

19. LOWRY OH, ROSEBROUGH NJ, FARR AL, RANDALL RJ (1951) Protein measurement with the Folin phenol reagent. J Biol Chem 193: 265-275.

20. Trevelyan WE, Harrison JS (1952) Quantification of sugars by the anthrone sulphuric method. Biochem J 23: 1824-1827.

21. ABEL LL, LEVY BB, BRODIE BB, KENDALL FE (1952) A simplified method fo the estimation of total cholesterol in serum and demonstration of its specificity. J Biol Chem 195: 357-366.

22. Rao LM, Patnaik RMS (1999) Heavy metal accumulation in the cat fish Mystus vittatus $(\mathrm{BLOCH})$ from Mehadrigedda stream of Vishakhapatnam, India. Pollut Res 19: 325-329.

23. Moiseenko TI, Kudryavtseva LP (2001) Trace metal accumulation and fish pathologies in areas affected by mining and metallurgical enterprises in the Kola Region, Russia. Environ Pollut 114: 285-297.

24. Nair M, Balachandran KK, Shankaranarayanan VN, Joseph T (1997) Heavy metals in fishes from coastal waters of cochin, southwest coast of India. Indian J Mar Sci 26: 98-100.

25. Brooks S, Tyler CR, Sumpter JP (1997) Egg quality in fish: what makes a good egg?. Review in Fish Biology and Fisheries 7: 387-416.

26. Grosell M, Boetius I, Hansen HJM, Rosenkilde P (1996Influence of preexposure to sublethal levels of copper on $64 \mathrm{Cu}$ uptake and distribution among tissues of the European eel (Anguilla anguilla). Comp Biochem Physiol C114: 229-235.

27. Almeida JA, Novelli EL, Dal Pai Silva M, Júnior RA (2001) Environmental cadium exposure and metabolic responses of the Nile tilapia, Oreochromis niloticus. Environ Pollut 114: 169-175.
28. Barber D, Sharma MS (1998) Experimentally induced bioaccumulation and elimination of cadmium in freshwater fishes. Pollut Res 17: 99-104.

29. Mount DI, Stephan CE (1967) A method for detecting cadmium poisoning in fish. J Wild Mgmt 3: 168-172.

30. Vincent S, Ambrose T (1994) Uptake of heavy metals, cadmium and chromium in tissues of Indian major carp. Catla catla (Ham). Indian J Environ Hlth 36: 200-204.

31. Allen P (1994) Accumulation profiles of lead and the influence of Cadmium and Mercury in Oreochromis aureus (Steindachner) during Chronic exposure. Toxicol Environ Chem 44: 101-112.

32. Oladimeji AA, Offem BO (1989) Toxicity of water borne lead to Clarias laser Oreochromis niloticus, Chironomous tetans and Benacus sp. Water Air Soll Pollut 44: 191-201

33. Annune PA (1992) Effect of cadmium and zinc on freshwater fish species, Clarias gariepinus, Burch and Oreochromis niloticus (Trewavas). Ahmadu Bello University, Zaria, Nigeria.

34. Bremner I, Davies NT (1975) The induction of metallothionein in rat liver by zinc injection and restriction of food intake. Biochem J 149: 733-738.

35. Kägi JH, Schäffer A (1988) Biochemistry of metallothionein. Biochemistry 27 8509-8515.

36. Nanda P, Behera MK (1996) Nickel induced change in some haemato biochemical parameters of catfish $\mathrm{H}$. fossilis . Environ Ecol 14: 82-85.

37. Chakrabarti P, Banerjee V (1989) Effects of sublethal toxicity of three organs phosphorus pesticides on the peripheral haemogram of the fish Channa punctatus. Environ Ecol 6: 151-158.

38. Nanda P, Nath DP, Behera MK (2002) Respiratory metabolism of fish Oreochromis mossambicus (peters) exposed to pulp and paper mill effluents. Environ Ecol 20: 570-572.

39. Kaviraj A, Das S (1995) Influence of Chelating agent EDTA, adsorbent activated charcoal and inorganic fertilizer (single super phosphate) or the histopathological changes in gill epithelium of common carp exposed to cadmium. Proc Nat Acad Sci India., 65: 305-308

40. Ruparelia SG, Verma Y, Meta NS, Rawal VM (1992) Cadmium accumulation and biochemical alteration in the liver of fresh water fish Sarotherodon mossambicus (peters). J Ecotoxicol Environ Monit 2: 129-136.

41. Goel KA, Gupta K (1988) Zn toxicity to a fresh water teleost, Clarias batrachus J Fish 32: 256-259.

42. Garg VK, Garg SK, Tyagi SK (1989) Manganese Induced hematological and biological anamolies in Heteropneustes fossilis. J Environ Biol 10: 249-353.

43. Putte IVD, Laurier MBHM, Eijk GJMV (1982) Respiration and osmoregulation in rainbow trout (Salmo gairdneri) exposed to hexavalent chromium at different $\mathrm{pH}$ values. Aquat Toxicol 2: 99-112.

44. Spry DJ, Wood CM (1984) Acid-base, plasma ion and blood gas changes in rainbow trout during short during short term toxic zinc exposure. J Comp Physiol 154: 149-158.

45. Majewski HS, Giles MA (1981) Cardiovascular-respiratory responses of rainbow trout (Salmo gairdneri) during chronic exposure to sublethal concentrations of cadmium. Water Res 15: 1211-1217.

46. Santos MA, Hall A (1990) Influence of inorganic lead on the biochemical blood composition of the eel, Anguilla anguilla L. Ecotoxicol Environ Saf 20: 7-9.

47. Haux C, Larsson A (1982) Influence of inorganic lead on the biochemical blood composition in the rainbow trout, Salmo gairdneri. Ecotoxicol Environ Saf 6 : 28-34

48. Fabbri E, Caselli F, Piano A, Sartor G, Capuzzo A (2003) Cd2+ and Hg2+ affect glucose release and cAMP-dependent transduction pathway in isolated ee hepatocytes. Aquat Toxicol 62: 55-65.

49. Larsson A, Haux C, Sjöbeck ML, Lithner G (1984) Physiological effects of an additional stressor on fish exposed to a simulated heavy-metal-containing effluent from a sulfide ore smeltery. Ecotoxicol Environ Saf 8: 118-128.

50. Mcdonald G, Milligan L (1997) lonic osmotic and acid-base regulation instress In: Iwama GK, Pickering AD, Sumpter JP, Schreck CB (Eds.) Fish stress and health in Aquaculture. Cambridge University Press, Cambridge, UK.

51. Martin LK Jr, Black MC (1998) Biomarker assessment of the effects of coa strip-mine contamination on channel catfish. Ecotoxicol Environ Saf 41: 307 320.

52. Vijayram K, Vasugi SR (1989) Sub lethal effects of pulp \& paper mill effluent on the biochemistry of a fresh water fish Rasbora daniconius. Ind $\mathrm{J}$ Environ HIth 3: 36-42. 
Citation: Nanda P (2014) Bioaccumulation of Heavy Metals and Physiological Response in Anabas testudineus on Exposure to Paper Mill Effluent. J Environ Anal Toxicol 4: 244. doi: 10.4172/2161-0525.1000244

Page 8 of 8

53. Singh MK, Prasad AK, Jha BS (1993) Impact of tannery effluent on blood and organ metabolic levels of the teleost $\mathrm{H}$. fossilis. Bio Sci Res Bull 9: 49-56.

54. Sastry KV, Rao DR (1981) Enzymological and biochemical changes produced by mercuric chloride in a teleost fish, Channa punctatus. Toxicol Lett 9: 321-326.

55. Oner M, Atli G, Canli M (2008) Changes in serum biochemical parameters of freshwater fish Oreochromis niloticus following prolonged metal $(\mathrm{Ag}, \mathrm{Cd}, \mathrm{Cr}$ $\mathrm{Cu}, \mathrm{Zn}$ ) exposures. Environ Toxicol Chem 27: 360-366.

56. Sastry KV, Sharma K (1980) Mercury induced haematological and biochemical anomalies in Ophiocephalus (Channa) punctatus. Toxicol Lett 5: 245-249.

57. Tietz N (1986) Textbook of clinical chemistry. W.B.Saunders co, Philadelphia PA 1919. 